\title{
AQUÍ SE PUEDE HACER ESO: \\ NIDO PROHIBIDO, CASA FAMILIAR Y BANQUETE DE JULIA DE BURGOS. LECTURA DE CARTAS A CONSUELO
}

\author{
POR \\ Juan Carlos Quintero-Herencia \\ University of Maryland, College Park
}

Yo canto con delirio.

La Lupe

El atardecer sanjuanero que acogió la presentación del libro Cartas a Consuelo se caracterizó por el calor y la humedad. La colección de cartas que enviara la poeta puertorriqueña Julia de Burgos (1914-1953) a su hermana Consuelo, por fin conocen la aptitud editorial gracias a la labor de Eugenio Ballou y el equipo de edición de Folium. Este trabajo editorial, como el efectuado por la investigadora principal y prologuista del volumen, Lena Burgos-Lafuente, coronan lo que sin duda es el acontecimiento literario puertorriqueño del año 2014-2015.

El 28 de mayo de 2015, en la librería La Tertulia del Viejo San Juan, apenas hubo espacio para una audiencia que llegó a arremolinarse en la entrada del local y, por momentos, obstruyó el ingreso a la librería, como la posibilidad de escuchar las valiosas presentaciones del libro leídas por los profesores Efraín Barradas y Sylvia Molloy. Los organizadores del evento, los presentadores del libro y el público que logró conseguir un asiento no sólo batallaron con el calor de la velada, además tuvieron que enfrentar no poca competencia del vocerío que venía de la calle. Muchos de los reunidos al interior de la librería escucharon las presentaciones del libro de pie. En algún momento durante la presentación, de la calle provinieron vivas a Julia de Burgos y vivas a Puerto Rico libre. Antes y durante la presentación del libro esta cámara de ruidos y consignas pareció amenazar la escucha del evento si llegaba a darle paso a la baraúnda de aspavientos y mojigangas identitarias que definen el culto, esa veneración antillana llamada Julia de Burgos. Ya el centenario de la poeta había sido motivo de innumerables actividades, ediciones y artículos de todo tipo. El homenaje como trompeta, tarja y lápida. Pero la presentación de las cartas de Julia de Burgos esa tarde no cedió su asiento al ruido de lo siempre igual y la masa de consignas siguió calle abajo. 
El aglomerarse del público aquella tarde no tendría que haber tomado por sorpresa a nadie. Entre el público de la presentación, además, había personas que recalaron allí tironeados quizás por razones de otra índole. En esos días, se celebraba en San Juan, el congreso anual de la Latin American Studies Association; la asociación profesional que cuenta con la mayor membresía de estudiosos de América Latina y el Caribe a nivel mundial. A esas horas las sesiones del congreso habría terminado.

La salida pública de este volumen habilita otro comienzo para la lectura de la obra literaria de Julia de Burgos. Cartas a Consuelo constituye un evento literario que marcará un antes y después para la crítica dedicada a la obra de la poeta puertorriqueña y para aquellos interesados en pensar la singularidad política de una poética puertorriqueña y los modos de discusión crítica que ésta genera. En estas cartas se nos abren fragmentos de la vida de Burgos y tal vez comienza el desbloqueo de otra temporalidad de sentidos y lecturas para la escritura de la poeta. Tanto Cartas a Consuelo como el número extraordinario de la revista académica del Center for Puerto Rican Studies, Centro Journal: Untendered Eyes: Literary Politics of Julia de Burgos (II, Fall 2014), editado por Burgos-Lafuente, representan la posibilidad de cambiar o abandonar ese uso talismánico, sacrosanto de los textos, la escritura y hasta la palabra política de Julia de Burgos. Burgos como talismán sería ese objeto retórico, catalejo moral y didáctico, que levanta cualquier oficiante en las ceremonias del apocamiento y la sananería institucional puertorriqueña. Esto vale para casi todas las instituciones oficiales como no pocas institucioncitas “alternativas". Sahumerios y espiritualizaciones discursivas, tautologías identitarias de todo tipo, llevan más de medio siglo encaramando la obra de Burgos (su retrato, algún poema, aquella carta) cual amuleto que aleje esa calamidad que supondría pensarla desde y con la complejidad que la atraviesa. Claro está, algunos proclaman que no se sabe si la misa que pasa por crítica se lleva a cabo con conciencia de sí misma. No hay que ser mal pensados y darles el beneficio de la duda, dirán: Qué bello es contemplar la prenda perdida, la joya arruinada por el exceso. En el caso de la poesía de Julia de Burgos, esta crítica talismánica parecería "corregir" la modernidad indiscutible de esta poesía al "devolverle" una extraña aura por vía de la manufactura discursiva de un fósil, la reanimación de un antepasado sentí-mental. Toda lectura talismánica puede ser apreciada como esa estructura vestigial, una suerte de rabo metafísico, que regresa florecido sobre el coxis de la crítica literaria. Un uso talismánico de la lengua crítica, incluso de lo que se imagina como lengua política, intenta construir una utopía absoluta desde la lengua del credo y el avivamiento. Esta lengua supuestamente interpelaría y por lo tanto constituiría una mejor comunidad puertorriqueña. Toda experiencia literaria leída al modo hocus-pocus imagina la forma literaria como piedra de toque donde los temas o el perfil biográfico de algún autor o autora se nos ofrecen en toda su gloria. Acceder y participar de este ceremonial transportaría una suerte de moralización del lector. Si se lee y se entiende lo que acarrea este sacrificio hecho letra, el lector devendrá bueno, tremendo-ser-humano. En

Revista Iberoamericana, Vol. LXXXII, Núm. 257, Octubre-Diciembre 2016, 873-890 ISSN 0034-9631 (Impreso) 
resumidas cuentas, leer al modo talismánico ayuda a que uno o alguien se supere. En el caso de Burgos se ha privilegiado ponerle cintillas, flores y manillas a las pasiones, sufrimiento y la carencia vivencial que recorren su vida y obra. Así se reinauguraría su "verdadera palabra" en el Panteón de La Inmolación Modélica Nacional y nos enseñaría el camino a seguir. ¡Cuántas horas de aburrimiento perfecto ordeñadas por alguna sandez didáctica, homogenizadas por alguna charrería bien intencionada o en el mejor caso, senil! "Julia, la bandera. Julia es Puerto Rico. Julia=LA MUJER, Julia es la diáspora. Nadie ha sufrido como Julia. Julia es EL DOLOR.” Julia de Burgos, ese extraño emb(o)rujo literario, con el cual el discurso identitario puertorriqueño hace del sufrimiento, del descalabro ético o de la estrechez, un anfiteatro discursivo -concha acústica verbal-donde (¡qué sorpresa!) nadie se presenta a escuchar.

Tampoco habría que subestimar el efecto espejo Julia de Burgos. Me refiero a la transformación del texto literario escrito por Julia de Burgos, incluso su yo poético, en espejo o avatar narcisista para el crítico o crítica de turno. Encantador este hechizo institucional, yoico de la poética de Burgos que pone a la crítica o al crítico a hablar de sí mismos o a señalarle a la autora lo que hizo, debió o dejó de hacer.

Ahora bien, me parece que la cualidad mayor de Cartas a Consuelo es la entrega de Burgos como sujeto contradictorio, la aparición del yo epistolar de Burgos como un sujeto complejo, poblado por dificultades, maravillas e insuficiencias. Esta correspondencia de Julia de Burgos a su hermana Consuelo recoge el trazo de un sujeto que ayudará a contradecir y a contrapuntear esa Julia heroica o patética, mítica y sufridora que se campea triunfante en más de un salón hogar de la crítica puertorriqueña. La misma Julia que siempre se ha imaginado hecha de una sola pieza. Cartas a Consuelo restituye, en otro horizonte, ese cuerpo que hizo sus textos con materiales, lecturas, y claro está, deseos y urgencias, como esas cartas que uno imagina Burgos escribe y despacha en el puerto justo antes de que partiera el vapor que las llevaría a su destino.

Esta correspondencia deja entrever un cuerpo escritural surgido, como casi todos, de la lectura y de la intemperie. No la hipostasis de alguna esencia sentimental dictada desde el más allá insondable de su corazón o en transmisión directa desde los santos lugares del nacionalismo puertorriqueño. Como señala Burgos-Lafuente, entre la circunspección y el guiño, en su sugerente Prólogo, "Yo, múltiple: las cartas de Julia de Burgos", Cartas a Consuelo se ofrece como un texto abierto, como un texto cosido de aberturas:

Podría decirse, como de la poesía, que cada carta dice mucho más de lo que dice, que cada frase o cada anécdota no vale por lo que denota sino por sus ecos, sus resonancias. $\mathrm{Y}$ es que este no es un texto de cierre. Lejos de suturar el sentido de una época o de una circunstancia determinada, las cartas de Julia de Burgos a su hermana Consuelo abren surcos, siembran vacíos que invitan al lector a agregar, especular e investigar aquello que sin decirse se dice. (xxiii)

Revista Iberoamericana, Vol. LXXXII, Núm. 257, Octubre-Diciembre 2016, 873-890 ISSN 0034-9631 (Impreso)

ISSN 2154-4794 (Electrónico) 
Sin atender por ahora esa agricultura averiada ( $\sin$ semilla), e intransitiva que nombra Burgos-Lafuente, se podría preguntar ¿cómo se inscribe lo no dicho entre las cartas? ¿Cómo escuchar la multiplicidad de palabras perdidas entre las cartas? ¿Cómo escuchar incluso las cartas desaparecidas que no hemos leído de Consuelo Burgos, como las que la propia Julia de Burgos dice haber enviado a familiares, amigos y escritores en su momento? Propongo, para empezar por algún lado, poner a discutir las aseveraciones, giros y proposiciones contradictorias que recorren estas cartas como también rastrear sus consistencias y los enormes silencios que hay en la correspondencia. También se podrían confrontar las cartas con el Diario de la poeta. Por el momento, por qué no lidiar con la extraña noción de presente, interpelación y presupuestos que sostiene toda carta. La carta como género, como género discursivo, suponía un tiempo en suspensión y hasta daba por sentado una interrupción considerable de la comunicación entre los que se carteaban. El género epistolar (ese género liquidado por el email, el mensaje de texto, los chats y Skype) no presupone un conocimiento puntual o un acceso instantáneo a la situación del destinatario del texto. De igual forma, quien escribía la carta trabajaba con una suerte de inmediatez distante que la carta aspiraba a tornar cercano, próximo, con su fecha, su saludo y la rápida descripción del presente de la escritura. Quien recibía una carta tenía tiempo para imaginar entre y con las palabras la situación de quien la escribía y viceversa, incluso podía darse el lujo de esperar, pensar y contestar. En fin, escribir cartas era acercar al destinatario a un lugar-tiempo subjetivo a través de la palabra escrita. Esperar la carta y responder a ella no se entendían como operaciones de comunicación instantánea.

En este sentido, uno de los temas (y son muchos) de esta conversación (donde prácticamente no se escucha a una de las interlocutoras) es el esfuerzo de Julia de Burgos por representarle a su hermana Consuelo el tiempo, sobre todo, el espacio de su vida cotidiana y cómo estos de alguna manera podían afectar o participar de la situación cotidiana de Consuelo. Este comunicarle a Consuelo su presente es inseparable de los constantes encargos de Burgos de fotos, cartas, gestiones burocráticas en Puerto Rico, artículos o reseñas con los que, por igual, intentaba rebasar requerimientos institucionales como registrar el estado de su carrera literaria. Durante la presentación sanjuanera de Cartas a Consuelo, Sylvia Molloy se refirió a un gesto que avasalla en la correspondencia. Se trata de esos continuos encargos propios de una madre o tía mandona con los que la hermana mayor en este caso establece qué se debe hacer y cómo se deben hacer las cosas. Estos encargos en imperativo recorren la mayoría de las cartas de Burgos donde se detallan la necesidad imperiosa de algunos mandados, consejos, envíos de recortes, instrucciones, pasos a seguir como órdenes o advertencias sagazmente acompañados de inagotables diminutivos. Incluso al momento de apalabrar su amor por la independencia de Puerto Rico. Recién llegada a La Habana, Burgos escribe:

Revista Iberoamericana, Vol. LXXXII, Núm. 257, Octubre-Diciembre 2016, 873-890 ISSN 0034-9631 (Impreso) 
¡Consuelín, por primer vez he pisado tierra libre de América Indohispánica! Es algo grandioso. Invoqué a Martí, y recordé tanta sangre puertorriqueña vertida en Cuba por la causa de la Independencia. ¡Dónde estarán esos hombres hoy! La bandera cubana, tendida por todos los horizontes me produjo una enorme sensación de tristeza. Es tan parecida a su hermana, la nuestra. Sin embargo, esta última ondula solamente en unos cuantos corazones puros, que han sabido guardarla del ventarrón fatal que ha arrancado la vergüenza a la mayor parte de nuestro pueblo. Consuelín, nunca olvides que para haber verdadera justicia social en nuestra tierra, llámese comunismo o lo que sea, tiene que primero ondear libremente, y sola, sobre cada edificio y sobre cada palma, una vez cruzado todo corazón, esa bandera monoestrellada que nos define hispanoamericanos en América. (42)

El uso del imperativo en la escritura epistolar de Burgos es un modo de dirigirse a su hermana naturalizado hasta tal grado que la poeta llegará a decirle a su hermana donde pasar las vacaciones (55), como también demandar los términos con los que Consuelo deberá nombrar a su amado Juan Isidro Jimenes Grullón, entre otros. Por favor, parece decir, dile Papá. Burgos lee las cartas de su hermana y las acomoda al interior de esa faena estratégica de amoríos y caricias dedicada a halagar y sostener la imagen de la masculinidad amada:

Quiero decirte, Consuelín, que noté que Juan sintió un poquito el que lo trataras de Jimenes nada más. ¿Se te pasó? Pon en tus cartitas siempre algunas frases de recuerdo cariñoso para él, pues te quiere mucho y es muy susceptible de cualquier manifestación de frialdad. ¿Te acuerdas cuando le gustaba decirte hijita? En la próxima habla mucho de él, que tienes deseos de verlo, etc. (87)

$[\ldots]$

Te envío unas revistas por correo. Ya tengo en mente algo para escribirte el dramita. Dime de qué largo. Empezaré mañana y tú podrás luego añadirle otras cosas. Algo campesino. Acuérdate ponerle frases cariñosas a tu "papacito". Escríbeme enseguida. Mándame lo del P.R. Ilustrado. Recuerdos a papá y abrazos a Iris y a todos.

Te quiere,

Julita (88)

Por otra parte, la correspondencia está repleta de detalles sobre la venta, circulación y discusión de la obra poética de Burgos que la propia Burgos requería y encaminaba. En ese sentido, las cartas a su hermana, también recogen los chismes, escaramuzas, enemistades como entendimientos o alianzas que la poeta deducía inherentes a los espacios institucionales donde se bregaba el "triunfo" literario de algún escritor puertorriqueño. En carta fechada el 12 de noviembre de 1940-donde Burgos menciona otra carta de "un joven de P.R." que nunca conoció- la escritora expresa su alegría por el triunfo de Luis Muñoz Marín en las elecciones de ese año:

Revista Iberoamericana, Vol. LXXXII, Núm. 257, Octubre-Diciembre 2016, 873-890 
Me alegro mucho de ese triunfo, pues es lo mejor que tenemos. Seguramente Géigel P. habrá salido senador, y Ramos Antonini, y algunos otros de nuestros amigos. Conviene por tanto, Consuelín, que te sigas viendo con esos muchachos, que sigas yendo al Ateneo para que no te olviden. Son ahora gobierno y pueden ayudarte si quieren. Fíjate en el periódico en la próxima reunión del Ateneo y ve a ella, para que saludes a todos esos muchachos y además para ver qué te preguntan y comentan sobre mí toda la fila de sombras que aun escolta mi recuerdo y cuéntamelo todo, y replícale bien a todas. No dejes de ir. Me dice Carmen Alicia que en P.R. sólo tengo cuatro amigas: ella, Isabelita Freire, Esther Feliciano (compañera mía de escuela) y Margot Arce (que extraño), de ahí en fuera todas son enemigas mías, y quisiera precisar, localizar, para algún día poner en conciencia los puntos sobre las íes. Tú eres la que me puedes averiguar algo. Sé diplomática, que allí siempre hay chismosas que te cuenten, como Carmen Marrero y Yeyita. Si ves a Cuchí Coll y te saluda, o te mira, dile que ella no es persona para saludarte. Es una canalla. Despréciala, pero que lo note. A las demás, frialdad absoluta, y agresividad. Es necesario que se den cuenta que yo estoy enterada de sus iniquidades. (82, énfasis mío)

(Dicho sea de paso. Es una pena alarmante no contar con cartas que coincidan con la creación y fundación del Estado Libre Asociado de Puerto Rico [1952] o con la Revuelta Nacionalista de 1950. Hay un salto o hueco enorme en el epistolario entre el 9 de marzo de 1949 al 20 de noviembre 1952 [208-209]).

El esfuerzo epistolar de Burgos es, en muchas ocasiones, una manera de aparecerse donde ya no está, ni puede estarlo de cuerpo presente; una forma de intervenir, incluso de afectar y hasta de resolver situaciones que están fuera de su alcance y en las que Consuelo es designada como su representante o como delegada de su voluntad:

Sé que el Domingo es Día de las Madres. Quiero que hagas algo en mi nombre y en mi alma, como si lo estuviese haciendo yo. De eso que te envío, compra algún papel y háganle algunas coronas para que se las lleven el domingo en su lecho eterno. Háganle una blanca y deposítenla con mi oración. Y en nombre de ella reciban todos mi bendición. Consuelín, ahí va mi programa del recital del viernes 10 de mayo. Si no me has enviado el traje mándamelo, pues tal vez me vaya la otra semana después de Juan. (35, énfasis mío)

Cartas a Consuelo es también el testimonio de cómo Burgos ya entendía y advertía con tono profético su eventual canonización en el imaginario puertorriqueño. La intensidad, creencias y pasiones de la escritora son inseparables de su preocupación consciente en torno a la visibilidad y destino de su obra. El lector de Cartas a Consuelo llega in medias res a un escenario familiar donde la poeta emigrada sabe que a sus 24 años es una escritora publicada con efectos manifiestos entre sus lectores. Este tema, el reconocimiento que pueden merecerle los libros sólo cederá su preeminencia ante los

Revista Iberoamericana, Vol. LXXXII, Núm. 257, Octubre-Diciembre 2016, 873-890 ISSN 0034-9631 (Impreso) 
relatos sesgados de amor y tormento junto a Jimenes Grullón o al final, sus búsquedas de empleo, su alcoholismo ("dolencia social” 220), enfermedad y postración final.

Cartas a Consuelo apuntala esa voluntad espacial, incluso corporal que trabaja sostenidamente la poética de Burgos. En este sentido esta correspondencia es una contribución a toda lectura dedicada a meditar el trabajo espacial -las maneras de dar espacio y construir espacios-que atraviesa su poesía. Inseparables de la labor imaginaria y metafórica con el espacio que organiza el pacto de lectura epistolar de la poeta con su hermana, hallamos los modos de auto-figuración de Burgos, su célebre auto-imaginarse como "yo" en la escritura, pero también su yo público y su yo político. Desde Cartas a Consuelo el célebre poema "Yo misma fui mi ruta" adquiere otro espesor. En su poesía es recurrente la indistinción compartida por los objetos y el sujeto poético. Indistinción que no es una simple tematización de la individualidad o de algún afán de unicidad yoica, originario para la voz. Este no poder discernir fronteras o lindes es una condición de la imagen y del lenguaje poético producido por Burgos a partir de su economía de mandatos.

Particular a esta correspondencia de Burgos a su hermana es la representación de su yo familiar, de su yo en familia: ese otro avatar íntimo de la ruta de Burgos. En sus cartas se hallan materiales e imágenes para seguir reflexionando sobre el sujeto que inscribe Burgos en su escritura, como también repensar la poderosa interlocución que su poesía estableció y establece con lo que precariamente he llamado, el ethos comunitario puertorriqueño. Este sujeto epistolar se impone ahora a todos aquellos que deseen reflexionar sobre su institucionalización en el canon literario de Puerto Rico. Recién recibido el premio de poesía por su libro Canción de la verdad sencilla (1939) Burgos vuelve a "retratarnos" el espacio-tiempo en que se encuentra al recibir la noticia del premio. Alli revela tener conciencia de lo que su obra ya representa en el campo literario puertorriqueño:

Cuando recibí la carta, Juan estaba a mi lado. Tembló de alegría, pues el triunfo no había sido sólo mío, sino también de él que lo inspiró desde la primera emoción hasta la última. En realidad si él no llega a P.R. y enciende como nunca mi vida en amor cósmico y eterno, no hubiera salido ese libro ni hubiera llegado este momento para mí. Sobre todo date cuenta que los premiados, hasta la fecha han sido veteranos en las letras puertorriqueñas, como Lloréns, Palés, Chevremont, Pedreira, Malaret, etc. Yo, empezando mi carrera literaria, a los 24 años de edad, y con un libro de versos, me debo sentir altamente complacida al recibir ese honor, que los años ni el mundo podrá quitarme. Además he sido la primera mujer premiada en el Instituto. (56)

La construcción del espacio y del yo en la escritura (temas medulares en la obra de Burgos) disponen a través del pacto de lectura contenido en Cartas a Consuelo otra recámara para percibir la condición subjetiva (íntima, corregiría Burgos) de quien

Revista Iberoamericana, Vol. LXXXII, Núm. 257, Octubre-Diciembre 2016, 873-890 ISSN 0034-9631 (Impreso)

ISSN 2154-4794 (Electrónico) 
escribe, lee y transita por esos espacios. El epistolario abre con la fascinación y el empeño ambulante de la recién llegada:

Aquí cada día abre nuevos horizontes, y cada paso dado es una maravilla en el apretado haz de las sensaciones. He caminado bastante por la ciudad, y me he perdido varias veces. Esta manía mía de atreverme a todo me ha hecho a los dos días de estar aquí, tirarme sola a caminar en bus. (9)

Recién llegada a Nueva York, Burgos goza incluso de algún tiempo para aquilatar "la belleza callada" en las afueras de Nueva York que contrasta con la luminosidad de Puerto Rico:

Esto es precioso, Consuelo. Aún en pleno invierno, con los árboles enormes pero color ceniza y sin una hojita, con la grama triste y amarilla, con las casas todas cerradas como escondiéndose del silencio invernal, es algo sumamente sensible al espíritu contemplar esta belleza callada que nos llega como nido prohibido que estamos descubriendo. Por que esta belleza es así, medio esquiva. En nuestros trópicos, claros como el sol que no se aleja nunca, todo se nos da pleno, desnudo, abierto. Aquí hay que desentrañar, rebuscar, meditar, para lograr la mano reveladora de la belleza. (22)

Este tipo de narración-ese acercarse lento al locus bello-desaparece prácticamente de las cartas según las condiciones de vida y trabajo de la escritora se tornen cada vez más atropelladas, precarias, abyectas.

Una fantasía familiar, un relato roto, crucial para su lectura crítica, recorre las Cartas a Consuelo y parecería que esta correspondencia nos lo brinda por primera vez. Los modos de registrar y trabajar las lógicas espaciales de su historia y cotidianidad en el extranjero -maneras inseparables de la economía de afectos y gestiones ordinarias que movilizan gran parte de las cartas de la poeta-inscriben fragmentos para reconstruir (narrar) un relato íntimo sobre los sentidos y deseos de la escritora en búsqueda de un espacio propio. Este relato familiar además opera como plantilla que primero registra, corrige luego, y al final complica lo que significa el viaje y la emigración de Burgos de cara a su familia en Puerto Rico. Si bien Cartas a Consuelo es, sin duda, el relato de la salida de un Puerto Rico que la asfixiaba de tantas maneras - "destierro" parece ser la palabra que prefiere Burgos para nombrar esta salida- también podría leerse como la escritura de una búsqueda de libertad íntima contrariada por las creencias de la propia escritora empeñada en quedar(se) de algún modo en la isla.

Esta fantasía familiar de Burgos posee dos registros en la correspondencia. Uno gravita en torno al hoyo negro de la madre muerta. Construir una casa propia como fungir como madre parece ser, en Cartas a Consuelo, un deseo condicionado a la construcción de un hogar para la familia que quedó en Puerto Rico - ofrenda a la madre muerta-. El otro registro es ese relato interrumpido, y luego imposible, del deseo de Burgos por

Revista Iberoamericana, Vol. LXXXII, Núm. 257, Octubre-Diciembre 2016, 873-890 ISSN 0034-9631 (Impreso)

ISSN 2154-4794 (Electrónico) 
hacerse de su propio espacio, de construirse una casa para su práctica como escritora. Esta imposibilidad doble -doble porque el vacío materno "debía" ser ocupado por ella como hermana mayor en la isla, y porque su errancia ética y precariedad laboral le evitarán las horas de lectura necesaria y el tiempo para escribir de forma sostenida sus textos- sin embargo, conforma un anhelo manifiesto de la Julia de Burgos de los tempranos años 1940. Sorprendida y entusiasmada por el premio que recibiera del Instituto de Literatura por Canción de la verdad sencilla escribe:

Me siento muy feliz. Lo único que ensombrece mi dicha es pensar que mi adorada madrecita no puede gozar de este momento tan hondo y trascendente, que su corazón haya palpitado junto al mío para gozar mi dicha, y que no participe ella de este triunfo mío, en todas sus formas. Una cosa me consuela, y es que ahi están ustedes para sustituirla a ella, y que a través de vuestros corazones y vuestro compartir con mi triunfo, participará ella desde su eternidad este momento único. Ya podrás terminar tus estudios, Consuelito, y tú sabes cuánto lo anheló ella. Además quiero ofrecerles a ustedes lo que ella estuvo esperando por muchos años; una casita, aunque sea humilde, pero que sea nuestra sin perturbaciones, hasta que mejoren las cosas. Por lo tanto comiencen todos ustedes a investigar por ahí, donde mejor les convenga, la compra de una casita como de $\$ 100$ o $\$ 125$. Yo sé que se consigue. Porque tú sabes que la primera que compró papá en Hato Rey fue de $\$ 150$ y era buena. Te digo de ese precio porque además está tu matrícula y otra ayuda para ustedes. Proyecto pagar a Baldrich y a Franklin parte de la deuda, porque ahora mis libros se venderán y como voy a estudiar, tendré gastos acá. Además quiero dejar una reservita para lo que se presente. Estando el problema de la casa de ustedes resuelto, para mí será más animado luchar. (56-57, énfasis mío)

La salida de Puerto Rico es vivida con desasosiego, tal vez hasta con culpa, por la poeta una vez entra en escena la situación de su familia en Puerto Rico. Debe anotarse que en la primera carta recogida en Cartas a Consuelo (21 de agosto de 1939), escrita en San Germán, Puerto Rico, la madre de Julia aparece enferma pero todavía viva: "Mucho me alegra el que mamá esté regular. Espero que pronto se pondrá buena. Dámele un abrazo fuerte de mi parte, y dímele que estoy a su lado en todo momento, y que la quiero mucho" (3).

Figurar a la madre, por lo tanto, es para la hija en el "destierro" una manera de habitar y habilitar su casa, un modo de estar con ella. La carta, en tanto género, también podría ser un avatar poético del deseo poemático en Burgos, entendido ahora como la ocupación averiada, utópica de la autoridad simbólica de la madre en la casa familiar. El poema-corona, el poema-casa, el poema-oración que, de manera contradictoria, precisa y niega la desaparición física que arrastra toda muerte. El poema-casa como aquello que acabaría la esperanza de la madre de tener un hogar. Burgos parece resistirse a deponer su "autoridad" familiar en el "destierro" pero tampoco asume el lugar materno.

Revista Iberoamericana, Vol. LXXXII, Núm. 257, Octubre-Diciembre 2016, 873-890 ISSN 0034-9631 (Impreso)

ISSN 2154-4794 (Electrónico) 
En medio de bretes asociados al "comportamiento" de una de las hermanas menores escribe en 1947:

Si en el aeropuerto no encuentra al Mr., me la llevo para casa. Tengo espacio, voluntad $\mathrm{y}$ amor para atenderla. Y por primera vez en mi vida me erigiré en madre, para ejercer sobre ella esa autoridad moral que tanta falta le hacía. (207, énfasis mío)

En esta correspondencia el padre no parece ser una opción o un hombro más en medio de esas luchas familiares que tanto ocupan a la poeta y a su hermana. Burgos, no concede por escrito a su hermana Consuelo la "jefatura" de la casa. Advertir que antes Burgos ha marcado esa condición colectiva del "ustedes" como sustitución y circunstancia para la "eternidad" de la madre. Julia de Burgos seguirá enviando dinero a sus seres queridos en la medida de lo posible.

En una temprana carta donde anota "el pequeño lastre que dejé para ti al ausentarme de mi isla”, como su desconcierto en Nueva York se lee:

Diles que deben estar todos esperanzados, que a pesar de la distancia estoy a su lado en espíritu, y que tan pronto pueda, mi mano será tendida hacia ellos, en el gesto maternal que me corresponde, una vez ida nuestra insustituible madre.

¡Oh Consuelo, cómo he recordado a nuestra adorada madrecita, en toda esa travesía y destierro! Aunque te entristezca, no puedo menos que decírtelo, pues no sabes qué terrible soledad me circunda, fuera de mi Juan, el siempre bueno y tierno. Él es la única chispa de luz y de calor en esta ola de hielo espiritual y físico. Pero mucho tenemos que sufrir con nuestras cosas íntimas, para agobiarlo con las mías personalísimas, como es esa pérdida sin comparación en las relaciones humanas. $L a$ llevo clavada en mi corazón como una rosa viva, y a cada paso la siento y recibo su abrazo misterioso. He soñado mucho con ella y con todos ustedes. Vive junto a nosotros, y por eso quiero que sea el centro de nuestras vidas familiares y que su senda sea nuestra armonía eterna. En cada momento triste y turbio que tengan Uds. piensen en ella, y óiganla, que la voz de una madre no se pierde en el vacío del tiempo, sino que cada día huérfano se vuelve un más hermoso mensaje de luz, una oración de claridad y amor. (6-7, énfasis mío)

Esta lengua propia de la devoción del creyente religioso, dedicada aquí al culto materno, rivaliza con la "posterior" lengua de la intelectual "cada día más y más atea" (113), como se describirá un año más tarde entusiasmada por el prólogo que le escribiría a su nuevo libro el intelectual comunista cubano Juan Marinello. O con enunciados como: "Tú sabes que yo no creo ni en Dios. Tú sabes que yo soy completamente materialista" (207). La escritura epistolar de Burgos dedicada al mandado y mandato materno, por lo tanto, es una manera de relocalizar los sentidos del espacio, del lugar e incluso de la vida misma, desatados por su salida de Puerto Rico. Prescribir el fervor

Revista Iberoamericana, Vol. LXXXII, Núm. 257, Octubre-Diciembre 2016, 873-890 ISSN 0034-9631 (Impreso)

ISSN 2154-4794 (Electrónico) 
materno es un modo sacramental de re-ligarse, atarse con la familia y vivir la fantasía consoladora de una re-unión a pesar de y gracias a la hendidura insalvable que abrió la muerte de la madre y la partida de la hija mayor. En la provincia habanera escribe sobre sus ansias de ver a su familia:

Pero no quiero ir a Puerto Rico. Cada día me aleja más de su superficie para encontrarme en su entraña, en lo más hondo de su corazón, en su bendita tierra hoy descansa nuestra Santa, con nuestras almas apretadas de eterno amor. Es por lo cual algún día futuro me decida volver en viaje de pájaro a mi patria: a besar la tierra que la guarda, y a llorar sobre ella mis lágrimas más tiernas. Por lo demás espero verlos a todos en el extranjero. Voy a adelantarle la idea que tiene Carmen de irse a Nueva York, pues así podrán reunirse todos y allí la vida es muy distinta para seguir con las costumbres de P.R. Y tal vez más tarde pueda irse hasta Papotito, pues allí encontraría trabajo enseguida. Veremos. (89)

Dos de los grandes presupuestos familiares de esta correspondencia son, primero, la hendidura que produce la muerte de la madre (grieta que angustia a Burgos en más de un sentido) y, segundo, la casi invisibilidad e irrelevancia simbólica del padre en todo este escenario de demandas y estrecheces. De hecho, el tejido de presupuestos que conforma la escritura epistolar revela que el género es un dispositivo que se activa y activa la escritura en un in medias res. Reducido a menciones ocasionales y salteadas, e identificado en otros momentos con el apodo (otra vez el diminutivo) de "Papotito", el padre de Burgos nunca exhibe la fuerza gravitacional o autoridad que tiene la madre.

Hay un gran silencio, un hueco silencioso entre estas cartas donde rumorea sordo este drama intenso (valga la redundancia) en torno a las circunstancias que vinculan ineluctablemente el tiempo de la salida de Burgos de Puerto Rico, la muerte de su madre y el subsiguiente duelo familiar. Las cartas de junio y julio de 1942 contienen la narración de Burgos de su separación definitiva de Jimenes Grullón. La "muerte" de ese amor imantará imágenes para ese "cuadro último" de la madre muerta y Burgos apenas puede soportarlo:

Te digo Consuelito que está muerto aquello tan enorme. Él rebajó con rencores pequeños y desbordada y brutal pasión aquello tan enorme. El profundo dolor se convirtió en indignación. No con él, sino con el hombre mismo. ¡Para mi no existe él, sino la humanidad! ¡Y qué pobre es! Ese rencor pequeño se ha cebado hasta con el cuadro último de nuestra santa madre. Me lo arrojó al rostro, y también a otras personas, como sacando en cara lo que hizo. Eso me volvió loca. Puedes decírselo. Él sabe que no miento. Le escribí, un profundo, desgarrador, pero implacable adiós. Y por veinte días, ya libre volví a ser yo. (156)

Un año después (1943) escribe desde Nueva York:

Revista Iberoamericana, Vol. LXXXII, Núm. 257, Octubre-Diciembre 2016, 873-890 ISSN 0034-9631 (Impreso)

ISSN 2154-4794 (Electrónico) 
En cuanto a lo que me dices del panteón de nuestra madrecita no tengo palabras para expresarte mi emoción y mi agradecimiento para Uds. dos. Tan terrible fue ese golpe para mi resistencia espiritual que me fui de P.R. sin siquiera ver su última morada. Solo puede conservarla un panteoncito para cuando yo regrese, si he de hacerlo algún día. Todos los meses te enviaré para contribuir a la hermosa y tierna idea. ¡Si pudiera ser para el 12 de octubre! (165)

La madre (muerta) operará como un centro vacío que actualiza el deseo de Burgos por una nueva casa para la sociabilidad y afectividad de la familia que ha quedado en la isla. La madre es además fantasma y voz, emanación espiritual y lenguaje, doble de la poeta en busca de escucha y permanencia entre su descendencia. De igual manera, la madre como recinto de "eternidad" (palabra clave en el vocabulario poético de Burgos) inscribe la demanda materna de Burgos de orden y estabilidad para su familia. Ese mismo centro puede configurarse en Nueva York cuando la poeta imagina la mudanza de sus familiares a la ciudad. Identificada con esta condición mortuoria y materna, el yo epistolar de Burgos que se mueve en estos espacios íntimos adquiere dimensiones que ameritan nuevas y mejores lecturas.

Si la carta a la hermana se escribe en las afueras, en el extranjero, durante los días del errar sin casa (simbólica o física) este no tener espacio mientras se transita por el extranjero devendrá, sin embargo, acicate de pequeñas utopías personales y familiares (incluida su escritura literaria). Estos viajes y mudanzas al comienzo de su "destierro" le ofrecen a la poeta fugaces vistas a un paisaje con promesa de escritura -pequeñas panorámicas que estimularán su escritura o donde se imagina produciendo contenta-. En Nueva York, marzo de 1940, en los inicios de su trabajo en el Censo de Nueva York:

Juan Zacarías me daba la lata hasta las 4:00 a. m. todas las noches, y en la mañana no podía dormir, ya que no había privacidad y además el nene de 4 años me caía encima a palos y a librazos. No pude sacar ni un libro mientras estuve allá, casi ni la ropa, pues lo que quería era levantarme y tirarme a la calle.

Hoy tengo mi casita: una habitación bien grande, con lavamanos, comedorcito, cocina de gas, closets y muchos muebles. Juan trabaja todo el día en un nuevo libro sobre Sto. Domingo, que publicará en Cuba. (25-26)

En efecto, la carta que contiene las oraciones racistas de Burgos sobre "los cocolos" de Harlem subraya su "autenticidad" desde la autoridad que se auto-confiere Burgos como sujeto que se ha metido en sus casas:

La mayor parte de esos negros son de Islas Vírgenes y Bermuda, Martinica, etc. -cocolos, que llaman. Viven en sus ritos salvajes, haciendo "brujerías" y quemando inciensos, prendiendo velas, etc. Todo esto lo he visto con mis propios ojos, pues he tenido que meterme en las casas, sentarme con ellos, y oír y ver su manera de vida. Es interesante

Revista Iberoamericana, Vol. LXXXII, Núm. 257, Octubre-Diciembre 2016, 873-890 ISSN 0034-9631 (Impreso) 
pero molesto y peligroso. [...] En realidad, esta es una experiencia que se puede tener una vez en la vida y nada más. Veremos a ver cómo salgo de esto. No puedo escribir ni una poesía, ni siquiera ver el cielo que se está ya poniendo un poquito claro. (27)

En contraste con sus estancias en Nueva York, el Edificio Carreño ante el malecón habanero ofrece otro paisaje:

Consuelo, estoy viviendo ahora frente a un paisaje precioso. Es en el mismo edificio enorme de 2000 personas, en el séptimo piso, en una habitación amplísima, que se eleva casi sobre el mar, frente al hermoso Atlántico. Solo se ve desde aquí mar y cielo pues queda a orillas del malecón, en la misma playa. Aquí escribiré mucho. Por esta enorme habitación limpia y fresca, con baño al lado, cocina, elevador a toda hora, pago solamente $\$ 13.00$ al mes. Compara con la de Sixtina. Juan Bosch vive también en el edificio y Juanín también. (63)

Son poquísimas y brevísimas instantáneas en las que se puede tocar el entusiasmo de Burgos. Estos momentos son análogos a esos agites de felicidad que experimenta la escritora al saberse leída, acogida y homenajeada por lectores de diverso tipo, desde estudiantes, el dominicano Juan Bosch, el cubano Raúl Roa, hasta el poeta Pablo Neruda. Inmersa en actividades de todo tipo-recitales, visitas a la redacción de revistas, entrevistas-, objeto de artículos y fotografías periodísticas, la escritora, electrificada de gozo, disfruta y avizora un futuro esperanzador para ella y su obra:

Yo sabía que saliendo de P.R. el mundo cambiaría para mí. Juan Bosch opina lo mismo que Roa, y donde quiera me presenta como la mejor poetisa de las Antillas. Yo estoy por creerlo. ¡Ja, ja! En verdad cada día me siento más satisfecha de mi obra y descubro nuevas fuerzas en mí. Me alegro por P.R. pues dondequiera que vaya seré P.R. Estoy haciendo una propaganda espiritual tremenda por mi tierra. He llorado algunas veces de dolor al contemplar la bandera cubana flotar, tan parecida a la nuestra. La he reclamado en sitios donde aparecen las demás hispano-americanas. Todo esto ha impresionado a la gente, y hasta en las escuelas se pondrá la bandera. Seré mensajera de la entraña de mi tierra indo-hispánica, y ya tú verás los resultados. (49)

Luego de una estadía en el oriente cubano, sobre todo en Santiago de Cuba, de regreso a La Habana el entusiasmo de Burgos por su vida como estudiante remonta, sin pudor alguno, las cumbres de la hipérbole:

Lo primero que quiero decirte es que ya nos mudamos a otra casa al mismo lado de la Universidad, muy buena y confortable. Tenemos cuarto con baño. Ya me matriculé, pero las clases no comienzan hasta noviembre. No me dices nada sobre la marcha de esta Univ. ¿Recibiste la carta? Yo aspiro a la vez cuatro doctorados y dos licenciaturas, que espero terminar en cinco años:

Revista Iberoamericana, Vol. LXXXII, Núm. 257, Octubre-Diciembre 2016, 873-890 
Dra. en Pedagogía
Dra. en Filosofía y Letras
Dra. en Ciencias Sociales
Dra. en Derecho Público
Lcda. en Derecho Consular y Diplomático

Aquí se puede hacer eso. Imagínate, voy a estar cargada de títulos. Llevo ahora 12 asignaturas de todas esas facultades: Griego, Latín, Francés, Biología, Antropología, Sociología, Psicología, Higiene Mental, Didáctica y muchas de Pedagogía. Estoy encantada pero será muy fuerte el curso, ya que llevo tres idiomas y dos ciencias. Ya te seguiré contando. ¿No me escuchaste por radio en la Universidad? Fue espléndido el acto y tengo retratos en los periódicos que te enviaré. (137)

Pero las casas en Cartas a Consuelo son espacios ocupados por otras familias, lugares de paso, espacios cedidos en hogares o camas cedidas por amigos como hospedaje a la poeta y a su amado. Cuando no es así, se trata de espacios alquilados a los amantes en búsqueda de una vida digna o escapando del acoso político o la precariedad. El ahogo por tedio y la soledad suprema experimentados por igual en New York, Washington DC ("capital del silencio" [194]) o en Santiago de Cuba, son inseparables de su acompañar, al principio, a Jimenes Grullón a través de sus dificultades políticas, familiares y económicas y luego parte de su brega para obtener y conservar algún empleo. Escribe Burgos desde la Provincia de La Habana, 16 de diciembre de 1940:

En estas últimas semanas no he escrito nada, pues el ambiente es muy duro para la emoción poética. Yo no sé ni puedo vivir entre familias. Y aquí tengo que hacerlo por obligación. Imagínate, la mitad de mis cosas, mi ropa y mis libros están en el cuarto de [Juan] Bosch, donde Juan me las tiene guardadas, hasta que me pueda fijar en un sitio seguro. Y tengo que esperar a que él venga los sábados con la llave, para sacar algo. Eso me angustia naturalmente. Pero creo que ya a final de mes se resuelva nuestra situación, y me pueda fijar en Santiago. Escríbeme aquí, hasta mi aviso. (90)

A pesar de moverse y disfrutar de La Habana, donde Burgos entra en contacto con el "elemento intelectual" (60) de la ciudad, lee poemas en público y en la radio, su estadía cubana (año y medio más o menos) es, otra vez, un periplo de estancias inestables, firmadas por esas mudanzas que le parecían una constante en su vida. Escribe desde el Edificio Carreño, La Habana, octubre de 1940:

Todavía permaneceremos algunos días más aquí. Voy a entregar los muebles. Durante seis años se ha repetido lo mismo, ¿te fijas? He tenido como quince juegos de cuarto, y todos por una razón o la otra, los he tenido que entregar a medio pago. De ahora en adelante los alquilaré, pues aquí hacen eso. (78, énfasis mío)

Revista Iberoamericana, Vol. LXXXII, Núm. 257, Octubre-Diciembre 2016, 873-890 ISSN 0034-9631 (Impreso) ISSN 2154-4794 (Electrónico) 
Estas cartas también son el registro parpadeante de la pérdida del espacio y el tiempo de la lectura, la pérdida de la biblioteca personal que en algún momento disfrutó la escritora. Cartas a Consuelo registra, por qué no, el itinerario funesto de una escritora que paulatinamente pierde el tiempo y el espacio mínimos para poder escribir. No poder estudiar, ni obtener una formación universitaria fueron renuncias que la poeta no aceptó con tranquilidad o resignación. En septiembre de 1940 en La Habana escribe:

En estos días yo estoy algo triste porque no he podido ver mi sueño de estudiar realizado. Todo este mes es de matrículas. Tú sabes que para mí el estudio es una de las grandes ilusiones de mi vida, inseparable en bienestar y en desgracia. ¡Y cómo me sacuden el espíritu y la mente los días de matrícula! Es que en realidad -24 años-, aún debería estar yo en aulas, si mi destino ambiental hubiese seguido a mi destino espiritual. [...] Pero no me doy por vencida. Ya vendrán mejores días. Para contrarrestar un poco este deseo vencido por ahora me he dedicado con ahínco a la lectura en estos últimos días. Acabo de leer María Antonieta de Stefan Zweig, mi autor favorito. Ahora leo Freud y Marx de Osborn, que te enviaré por vapor. He comprado varios libros. Tú sabes cuán amante soy de ellos. El nuevo libro de Juan -La República Dominicana- sale dentro de dos semanas. Es un estudio elevadísimo, sumamente serio, de la historia dominicana: una interpretación marxista de su realidad espiritual y biológica. (68)

Fascinante también es imaginar la potencialidad de Burgos como lectora; fantasear con la productividad de la Burgos lectora que también perdimos. Leer los efectos de ese hálito de ilusión que echaba mano entonces a esos mamotretos como una faena del amor. De la cita, sin embargo, se desprende la predilección de Burgos por la biografía, luego el ensayo histórico filosófico centrado en la figura del autor. Estos textos abocados a especificar la materialidad de sus objetos o las poses paradigmáticas de sus protagonistas sin duda animaron una de las preocupaciones temáticas más visibles en su poesía: la construcción de su identidad en el poema como agudamente anota Burgos-Lafuente en el "Prólogo" de la correspondencia (xviii-xix). Para Burgos leer biografías implica acercarse a la persona pública, a la figura aurática del Autor o de la Figura Histórica que debe ser recordada por su intensidad al vivir. Aún así, la lectura y el libro constituyen el rostro de ese otro amor, ese otro amante imposible de Julia de Burgos.

\section{LA BOCA DE JULIA}

¿Cuán posible es la felicidad para aquel o aquella que cree que existe y que ésta puede ser alcanzada con tan sólo desearla y trabajar por ella, cual si fuera el destino o un premio por sólo creer en ella? La felicidad como futuro, "triunfo", "eternidad". Si bien Cartas a Consuelo nos devela una Julia viva y briosa, irónica, rabiosa y apasionada que nos servirá para contrarrestar esa suma casi perfecta de tragedias y fracasos con los que cierta crítica se cebó por décadas, la tristeza y la penuria siguen ahí erizadas en más de

Revista Iberoamericana, Vol. LXXXII, Núm. 257, Octubre-Diciembre 2016, 873-890 
un verso y entre esta correspondencia. El desasosiego caribeño tiene una voz poderosa en la Julia de Burgos de El mar y tú (1954). La ansiedad y pugna ante la finitud, las pasiones negativas son parte de su registro tonal y uno de sus temas recurrentes. Es extremadamente difícil (cuando no irrelevante) para la crítica, a pesar de todo lo que añade al conocimiento público esta correspondencia, construir una contra-Julia, una Julia feliz, satisfecha, que borre la Julia lacrimosa y eternamente desdichada. Por otra parte, ¿por qué no considerar críticamente y sin cortapisas los beneficios simbólicos e ideológicos que transporta esa Julia víctima de todos, inocente y pura en medio del desastre? ¿Qué reprimió y malogró esta mistificación piadosa en términos poéticos y políticos? ¿Cuán posible es apalabrar hoy ante sus versos la difícil responsabilidad que demandan las pasiones y toda elección íntima? En el sujeto Julia de Burgos, poético y epistolar, habita un particular sujeto escindido que vive dicha escisión como un destino o como una circunstancia furtiva, inevitable y fatal. Marzo de 1940:

Me dices que a mí me pasa algo más hondo de lo que dejan ver mis palabras. No, Consuelín, cierto que no me pasa nada anormal, es el ambiente demasiado equilibrado en que me encuentro, que paradójicamente, desequilibra un poco mi existencia. Es la nueva forma de vida a que de por fuerza tengo que amoldarme, lo que me agobia y entristece primordialmente. Lo demás tú lo sabes. Esta vida partida en dos que estoy viviendo, entre la verdad y la mentira, entre la esencia y la forma, entre el golpe implacable de las circunstancias, y el eco tibio y suave del amor que me llama. Es la misma tristeza de Puerto Rico, aunque más acentuada, porque aquí se ha herido la esperanza de una dicha completa, que allá estaba fresca y esperando. Pero ya pasará. Y mientras tanto, ser fuerte. Como tú, he creado un enorme estoicismo en mi conciencia para soportar los latigazos del destino. Cómo me contemplaba yo misma en tus palabras, al leer en tu carta de tu actitud de valor frente a la vida. Consuelito, tú y yo tenemos mucho de parecido, y cada día nos acercaremos más. (18, énfasis mío)

Tal vez esta sea la fuerza y error trágico de esta poética, el nudo indisoluble de este ars amandi, de esta sentimentalidad poética de difícil circulación entre muchos lectores: ese sujeto que para amar - con gesto propio de diva de la época de oro del cine mexicano- debe escoger entre el todo o la nada, la vida o la muerte, la luz o la oscuridad. Mucha de la fascinación puertorriqueña por esta gestualidad de Burgos es avivada por este tono y la irreflexiva adhesión a esa batalla entre polos absolutos. La "escisión" es la incorporación de esta falsa polaridad que "obliga" a escoger y ante la cual no parece haber salida. La tristeza aquí es esa pasión que necesitaría amoldarse, domesticarse para que el sujeto público pueda acceder a una felicidad o libertad hueras. Este sujeto epistolar no cuestiona la necesidad, la obligatoriedad del dos, de la dualidad que firma el espacio que constriñe su situación vivencial, o al menos Burgos no cuestiona la naturalización social de este binario terminante donde se tomarán "decisiones supremas [que] son para siempre" (152). Hay momentos cuando Burgos imagina una

Revista Iberoamericana, Vol. LXXXII, Núm. 257, Octubre-Diciembre 2016, 873-890 
superioridad moral y política en el pathos del dolor y del goce. Allí muestra y expone mucho de la afectación que firma zonas considerables de su sentimentalidad poética. Mientras invita a sus hermanas a mudarse a Nueva York escribe:

Para ustedes no está mal el ambiente, pues tienen un temperamento un poco menos formado que el mío, y no sienten tan hondo o no han visto todavía la gran tragedia humana. Yo, dondequiera que vaya, recogeré todo el dolor, y dejaré pasar sin interesarme, todo aquello que sea alegría a cambio de mi alma, ya hecha a otros matices. (17, énfasis mío)

La aceptación conflictiva de esta plantilla moral y tonal (alma o cuerpo, puro o sucio, blanco o negro) es lo que en parte, me parece, nombra con mucho cuidado Burgos-Lafuente como la "internalización" de ciertas "convenciones sociales" (xxiii) por parte de la poeta. También su última poesía está llena de imágenes donde los vehículos, herramientas o las naves que moverían o liberarían al sujeto poético son contrariadamente la forma misma de su encierro, fijeza y muerte. Hay una diferencia fundamental entre advenir a la forma y amoldarse, entre producir ese espacio que figure una poética del delirio o la pasión amorosa como felicidad del instante, y aspirar a esa felicidad aparente, producto del adaptarse a algún modelo para el bien hacer o el bien decir en sociedad.

Por fortuna, la correspondencia de Burgos también recoge las reticencias y resistencias a más de una imposición social, como la opaca circunstancia del rompimiento de la relación amorosa con Jimenes Grullón. El relato del rechazo familiar, sea por razones de raza o de clase social, no parece hacerle justicia a lo que, tanto Burgos como Jimenes Grullón sugieren, provocó la separación de la pareja. Burgos:

A veces, para salvar algo hermoso hay que destruirlo, para que no caiga mustio y envilecido por nuestras miserables manos humanas. Nada más puedo decirte. Compréndeme. Y no hagas nada por enmendar lo trozado. Tú sabes que cuando tomo decisiones supremas son para siempre. (152)

Jimenes Grullón:

Ella es, Consuelo, culpable en grado extremo. Te lo digo con profundo dolor, pero también con indignación, porque habiendo sido yo lo que fui para ella, nunca pude concebir que me pagara con la deslealtad y la falsía que lo hizo. Espero algún día encontrarte y contártelo todo... ¡Es algo horroroso, incalificable! Pasaría horas enteras relatándote los hechos de que tengo conocimiento y la manera cínica con que ella me los escondió casi hasta el último momento. (229)

Revista Iberoamericana, Vol. LXXXII, Núm. 257, Octubre-Diciembre 2016, 873-890 ISSN 0034-9631 (Impreso) 
En fin, Cartas a Consuelo tampoco deja de regalarnos imágenes o sacudimientos que ayuden a entender ese abrazo que más de un lector puertorriqueño, por generaciones, le ha regalado a la poeta. Me refiero a esos momentos cuando la voz está ahí, a la mano, susurrante en el oído, casi en cuerpo presente y representa sin temor la fuerza de su gozo y de sus apetencias. Aquí escribe sobre sus días en Trinidad, Cuba:

Es como un mundo antiguo, sin destrozarse nada viejo ni construirse nada nuevo. Hoy vamos a tomar fotografías. Te las enviaré. He comido mangos, he corrido por la montaña, y me he puesto flores en la cabeza. Es divino esto. (49)

Y así, sin aspavientos, ni retóricas, de repente, la poeta avista otro modo de cortar distancias, de regresar a Puerto Rico o ajustar cuentas con su "destierro". Ahora sentada sobre la mesa sueña con volver a su casa, no a pasar meramente la noche, ni a cumplir algún destino o mandato histórico supremo, sino con disfrutar de un banquete. Julia de Burgos saborea ahora lo mejor de la cocina puertorriqueña, sus imágenes:

Es terrible la vida aquí para quienes no nos podemos apartar de lo puertorriqueño en todo. Cuando vayamos a Puerto Rico nos desquitaremos; ya tengo el menú preparado: un corral de jueyes constantemente repleto, y un lechón asado cada dos días. Los peces los tenemos en Vieques, pero los camarones me los tendrá que proporcionar Papotito. Hasta sueño con las buruquenas. (184)

Se han perdido las cartas donde se demuestra que los poetas José Lezama Lima y Luis Palés Matos habrían sido invitados.

[Nota a los lectores: Este ensayo, de ningún modo, debe ser leído como un ensayo que discute situaciones, sujetos o temas limitados al pasado siglo XX puertorriqueño.]

\section{OBRAS CITADAS Y CONSULTADAS}

Burgos, Julia de. Cartas a Consuelo. San Juan: Folium, 2014.

El mar y tú. Otros poemas. Río Piedras: Ediciones Huracán, 1981.

Burgos-Lafuente, Lena, ed. Centro Journal: Untendered Eyes: Literary Politics of Julia de Burgos II (2014).

Rodríguez Pagán, Juan Antonio. Julia en blanco y negro. San Juan: Sociedad Histórica de Puerto Rico, 2000. 